\title{
An empirical analysis of income distribution in West Virginia
}

James Bukenya

Follow this and additional works at: https://researchrepository.wvu.edu/ wv_agricultural_and_forestry_experiment_station_bulletins

\section{Digital Commons Citation}

Bukenya, James, "An empirical analysis of income distribution in West Virginia" (2000). West Virginia Agricultural and Forestry Experiment Station Bulletins. 725.

https://researchrepository.wvu.edu/wv_agricultural_and_forestry_experiment_station_bulletins/615 @ WVU. It has been accepted for inclusion in West Virginia Agricultural and Forestry Experiment Station Bulletins by an authorized administrator of The Research Repository @ WVU. For more information, please contact ian.harmon@mail.wvu.edu. 


\section{An Empirical Analysis Of Income Distribution \\ In West Virginia}

James Bukenya, Tesfa Gebremedhin, Denny Smith, and Peter Schaeffer

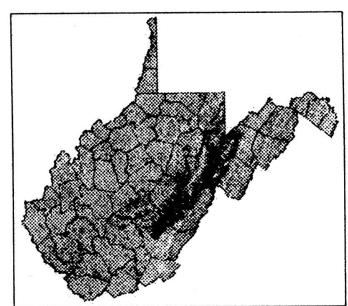

West Virginia Agricultural and Forestry

Experiment Station

Bulletin 725

\section{RECEIVED}

JAN 24.2003

FUAMBDALE LIDRARY

WEST VRGINA UWVERSITY 
West Virginia University is an Equal Opportunity/Affirmative Action Institution. The University does not discriminate on the basis of race, sex, age, disability, veteran status, religion, sexual orientation, color, or national origin in the administration of any of its educational programs or activities, or with respect to admission or employment. Further, faculty, staff, students, and applicants are protected from retaliation for filing complaints or assisting in an investigation under the University's Equal Opportunity/Affirmative Action Plan. Inquiries regarding the University's non-discrimination policy may be directed to the director, Affirmative Action Office/Equal Employment Opportunity Programs, West Virginia University.-Office of the President

West Virginia University is governed by the West Virginia University Board of Governors and the West Virginia Higher Education Policy Commission.

West Virginia Higher Education Policy Commission: J Michael Mullen, Chancellor, Charleston, WV; John R. Hoblitzell, Chair, Charleston, WV; Shawn R. Williams, Vice Chair, Clarksburg, WV; J. Thomas Jones, Secretary, Huntington, WV; Elliott G. Hicks, Esq., Charleston, WV; Ron D. Stollings, M.D., Madison, WV; Kay H. Goodwin, Charleston, WV; David L. Stewart, Charleston, WV; Mary Clare Eros, Esq., Shepherdstown, WV; HEPC Website: http://www.hepc.wvnet.edu/index.html

Board of Governors, West Virginia University: Cathy M. Armstrong, Secretary, Wheeling, WV, Term Expires 2004; Curtis H. (Hank) Barnette, Vice Chair, Bethlehem, PA, Term Expires 2004; Samuel A. Chico, III, Morgantown, WV, Term Expires 2002; Elizabeth E. (Betty) Chilton, Charleston, WV, Term Expires 2003; Dr. Paul Gates, DDS, MBA, Bronx, NY, Term Expires 2004; Terry T. Jones, University Relations Chair, Morgantown, WV, Term Expires 2004; Vaughn L. Kiger, Chair, Morgantown, WV, Term Expires 2005; Douglas J. Leech, Student Affairs Chair, Morgantown, WV, Term Expires 2003; T. Joseph Lopez, Business Affairs Chair, Arlington, VA, Term Expires 2005; Thomas E. Potter, Academic Affairs, Chair, Charleston, WV, Term Expires 2003; Rodney K. Thorn, East Rutherford, NJ, Term Expires 2002; Sandra M. Weese, Middlebourne, WV, Term Expires 2002; Roy S. Nutter, Faculty Senate Chair, Morgantown, WV; Paul R. Martinelli, Classified Staff Rep., Morgantown, WV; Jeremy A. Posey, Student Rep., Morgantown, WV. 


\title{
An Empirical Analysis Of Income Distribution In West Virginia
}

\author{
James Bukenya, Tesfa Gebremedhin, \\ Denny Smith, and Peter Schaeffer
}

\section{Table of Contents}

$\begin{array}{lr}\text { Abstract } & \text { ii } \\ \text { Introduction } & 1 \\ \text { Literature Review } & 2 \\ \text { Estimation Methods and Empirical Results } & 4 \\ \quad \text { Measuring Income Convergence } & 4 \\ \text { Non-parametric testing for } \sigma \text {-convergence } & 4 \\ \quad \text { Empirical Results } & 5 \\ \text { Correlation Analysis } & 7 \\ \quad \text { Empirical Results } & 8 \\ \text { F-test for Convergence } & 12 \\ \quad \text { Empirical Results } & 12 \\ \text { Time Series Analysis } & 12 . \\ \quad \text { Empirical Results } & 13 \\ \text { Parametric Testing for } \beta \text {-Convergence } & 15 \\ \quad \text { Empirical Results } & 15 \\ \text { Summary and Conclusions } & 20 \\ \text { References } & 22\end{array}$

The authors are, respectively, Former Graduate Research Assistant, Professor of Agricultural and Resource Economics, Associate Dean of Academic Affairs, and Professor and Director, Division of Resource Management, Davis College of Agriculture, Forestry, and Consumer Sciences, West Virginia University. The authors acknowledge the review comments of Dale Colyer, Gerard D'Souza and Scott Loveridge.

This research was supported by Hatch funds appropriated to the West Virginia University Agricultural and Forestry Experiment Station. 


\begin{abstract}
The main objective of the study was to examine the distribution of per capita incomes among the study areas. Both cross-section and time series data were used to test the convergence hypothesis. Several approaches of examining convergence were used: $\sigma$ convergence test, correlation analysis, F-test for convergence, time series analysis and $\beta$ convergence test. First, the results concurred with the conclusions reached by previous studies that divergence in the 1970s replaced the convergence that was observed in earlier decades. Second, the results showed that the gap in per capita real income between the southern and Eastern Panhandle counties had narrowed after the 1960s. Third, the results suggest that the rate of migration and the employment structure of the regions influenced the speed of convergence in per capita real income. Fourth, the data revealed that before the 1980s average per capita real incomes in the southern counties were higher than average per capita real incomes in the Eastern Panhandle counties. However, this trend was reversed during the 1980s. Lastly, the findings showed that there is a wider dispersion in personal disposable income across the counties than in personal income per capita and personal income minus government transfers. The results suggest that the effects of factor mobility and relocation of firms on the convergence process might have reached their limits in reducing regional disparities. From a policy perspective, the results suggest that reductions in personal direct taxes, and increases in government transfers and, possibly, other government assistance programs are the alternative tools for use by policy makers to further close regional gaps.
\end{abstract}




\section{Introduction}

The descriptions and diagnoses of United States trends in income inequality have exerted a great influence on debates over the minimum wage, trade agreements, labor law reforms, and tax policies. Changes in these areas alter the earnings opportunities of workers and may impose constraints upon workers' earnings. Not all changes in income distribution are related to markets, however. Income inequality in the U.S. is also closely connected to individuals' choices of family structure.

Since the earnings of individual family members combine to form family earnings and wage earnings comprise the bulk of family income, factors affecting the shape of the earnings distribution alter the shape of the family income distribution. Unlike the distribution of family incomes, however, individual earnings were not characterized by growing inequality until the 1980s. Presumably, changes in family structure and work patterns altered the shape of the family income distribution relative to that of individual earnings.

Government policies at both the federal and state levels have been reported to have an impact on the distribution of income. While government policies may not be able to counter economic forces that have led to increased income inequality, it is possible for labor policies and government programs that provide assistance for low- and middleincome people to affect the income distribution.

In light of previous studies on convergence (Barro and Sala-i-Martin, 1991; Browne, 1989; Carlino, 1992; Garnick, 1990), the main objectives in this study are twofold. First, we study the comparative growth of per capita incomes in southern West Virginia counties and in the Eastern Panhandle counties. Second, we test if West Virginia county data support the view that convergence of incomes at the level of regions was replaced by. divergence in the 1980s.

This study serves several purposes. First, it examines the relationship between the southern and eastern Panhandle regions, based on income distribution. Second, income is identified in the literature as one of the key variables in explaining how individuals form their needs to create life satisfaction. Therefore, investigating the differences in income distribution among individuals across the two regions is tantamount to examining regional differences in quality of life satisfaction. Third, the exercise explains the apparent contradiction between the convergence results obtained in recent research (Drennan and Tobier, 1996; Cheshires and Carbonaro, 1995; Neven and Gouyette, 1995; Barro and Sala-i-Martin, 1991) and the pessimistic view that prevailed in the early 1980s (Baumol, 1986; Garnick, 1990). Does the contradiction follow from the improvement of statistical techniques used in recent studies or from the historical record? While an analysis of this nature could be misleading, its results may serve to motivate a more detailed analysis of regional disparities. Lastly, examining the evolution of county disparity patterns can provide insight into the appropriate theoretical framework for understanding county growth trends. 


\section{Literature Review}

Convergence theory is a spatial extension of Kuznets' (1955) analysis of the evolution of income inequality across households. The theory asserts that regional disparities widen during the first dvelopment stage of transition to an industrial economy. They remain stable at a high level during a second stage that can last for a considerable time, depending on the speed of adjustment of the population across regions and on the strength of market forces. In the third stage, as the country matures, regional disparities in income per capita follow a steadily decreasing trend toward their long-run value (Kuznets, 1955).

However, recent empirical work casts doubt on the theory that economies converge to a stable steady state (Quah, 1993; Romer, 1994). For example, Quah (1993) finds that the unstable growth of real economies is largely inconsistent with the notion of convergence toward a steady state growth path. Quah argues that one cannot make inferences about the dynamics of the distribution of economies from simple cross-section regressions. The empirical analysis in Lee, Pesaran, and Smith (1997) reaches a similar conclusion. Cheshire and Carbonaro (1995) observe that the detection of $\beta$ convergence is merely a sign that the data are consistent with neoclassical theory and not a test of diminishing returns to capital or of the income-equalizing effect of factor mobility. They see the estimated $\beta$ as the net effect of a number of processes. Some of these processes, for example regional policy, labor mobility, or technological diffusion, cause convergence, but others, such as increasing returns, cause divergence.

In the cross-country convergence literature numerous studies (Barro and Sala-iMartin, 1991; Baumol, 1986; Mankiw, Romer and Weil, 1992) have found negative relations between initial per capita income and subsequent growth in per capita income after controlling for other variables that affect per capita income growth. In other words, these studies find conditional $\beta$ convergence, which is what the neoclassical growth models of Solow (1956) and Phelps (1966) predict. Nevertheless, many of the studies suggest that convergence among developed countries is a post-World War II phenomenon (Taylor and Williamson, 1994; Williamson, 1992, 1995; Williamson, O'Rourke and Hatton, 1993).

Carlino and Mills (1993) and Bernard and Durlauf (1991, 1993) have taken a time series approach to measuring convergence. The advantage of time series analysis is that the movement of per capita income in each region can be clearly and visually examined, while the disadvantage is that there currently is no way to measure how fast per capita incomes converge (Baffes and Ajwad, 1998). Carlino and Mills (1993) and Bernard and Durlauf $(1991,1993)$ argue that stationarity and temporariness of the shock in per capita income implies $\beta$-convergence, while stationarity, cointegration, and reducing variance movement together impliy $\sigma$ convergence ${ }^{2}$ of per capita income.

\footnotetext{
${ }^{1} \beta$-convergence would be observed if, in a cross-section data set, economic units that are initially poor tend to grow faster than rich ones.

${ }^{2}$ In this instance convergence is viewed as the reduction of the differences in incomes across regions over time, typically measured through the standard deviation of the regional market price distribution. This is perhaps the oldest notion of convergence in the academic literature, as several classic region investigations were based on such a measure (Kuznets, 1955; Easterlin, 1960; Williamson, 1965), while intuitively,
} 
By examining the random walk and temporariness of the shock, Carlino and Mills (1993) support the neoclassical growth model's prediction of per capita income convergence among US regions. Bernard and Durlauf $(1991,1993)$ test the convergence of real GDP for the period 1900-1988 in OECD countries by examining the random walk, cointegration, and variance movement over time. They find common trends in real GDP for OECD countries, but not convergence of real GDP. Thus, their results contradict the convergence evidence of other cross-sectional studies.

The question of regional income distribution has also commanded an extraordinary amount of attention (Cuadrado-Roura et al., 1999; Fingleton, 1999; Rey and Montouri, 1999; L'opez-Bazo et al., 1998; Bernard and Jones, 1996; Chatterji and Dewhrst, 1996; Quah, 1996b; Sala-i-Martin, 1996). Empirical studies have shown that poorer regions grow faster than richer ones (Sala-i-Martin, 1996; Armstrong, 1995; Neven and Gouyette, 1995; Persson, 1997). For example, Sala-i-Martin (1996) found that the dispersion of per capita real income between U.S states dropped during the $20^{\text {th }}$ century. Persson (1997) found that per capita real income among Swedish counties converged between 1911 and 1993. A study of the impact of the European regional development fund and of public investment in infrastructure and education on income levels across Spanish regions also supports convergence (de la Fuente and Vives, 1995).

Economic theory tells us to expect that differences in regional incomes will lessen over time (in a market economy), particularly within nation-states (Hicks, 1932; Drennan and Tobier, 1996). In the historical experience of the US, the convergence of regional income, whatever the measure of income used, has been persistent and strong (Barro and Sala-i-Martin, 1991; Borts, 1960; Perloff, 1963; Garnick and Friedenberg, 1982). In the 1980s, however, convergence of incomes was replaced by divergence. This interruption of the long-term convergence trend is widely documented (Barro and Sala-i-Martin, 1991; Browne, 1989; Carlino, 1992; Garnick, 1990). The most thorough analysis of divergence in the 1980s is found in Garnick (1990). He decomposed per capita personal income growth into its components and found that divergence was fully accounted for by three factors: growth in regional earnings, the employment to adult population ratio, and less important, the industry mix. Browne (1989) identified changes in per capita earnings as the primary source of regional income divergence in the 1980s, particularly in what is labeled as locally oriented industries. Carlino (1992) argues that convergence is the long-term norm and that the divergence observed in the 1980s is due to shocks whose effects are not likely to be repeated.

simple measures of $\sigma$-convergence do not provide insights as to the process that may be driving the narrowing (or widening) of the regional market prices/incomes. 


\section{Estimation Methods and Empirical Results}

Typically, the analysis for this study focuses on annual time series data for three different types of per capita real incomes: personal income, personal disposable income and personal income minus government transfers. Such an analysis contributes to the literature on per capita income convergence in two respects. On the theoretical side it introduces a measure of income convergence and identifies its source (i.e., short-run price transmission versus long-run cointegration). On the empirical side it tests the convergence hypothesis using both cross-sectional and time series data.

Secondary data are employed to analyze income disparities between the two study areas in West Virginia: counties in southern West Virginia and counties in the Eastern Panhandle region. Data on three types of per capita real income were obtained from the Bureau of Economic Analysis (BEA, 1999) starting from 1969 to 1998. The three types of per capita real income are personal income per capita (PI), personal income minus government transfers per capita (PIT), and personal disposable income per capita (PDI), which is personal income minus personal direct taxes.

No county-specific price indices are available. To get an accurate representation of each county's per capita real income, the analysis follows Persson's method and adjusts the counties' incomes, deflated by the state consumer price index, to account for differences in price levels across counties (Persson, 1994). Data on the state consumer price index were obtained from the Bureau of Business and Economic Research (BBER, 1999).

To control for sectoral shocks that affect growth in the short run, the analysis uses Sala-i-Martin's method and includes measures of the relative proportions of employees in agriculture and industry for various years (Sala-i-Martin, 1996). Data on these variables were obtained from the Regional Economic Information System (REIS, 1999). Another variable believed to affect the process of convergence, is migration across regions (Barro and Sala-i-Martin, 1995, Ch.9). To control for the effects of migration, measures of the average annual rate of migration into county $i$ between time $t-T$ are included. The migration data were obtained from the U.S. Census Bureau (USCB, 1999).

\section{Measuring Income Convergence}

Several quantitative or statistical approaches are available for evaluating the correlation and convergence of household income variables over time (Jeong, 1995; Baffes and Ajwad, 1998; Sala-i-Martin, 1996). Of these approaches, the current study employs $\sigma$ convergence test, correlation analysis, F-test for convergence, time series analysis and $\beta$ convergence test, to examine the degree of income disparity between the counties in the southern and Eastern Panhandle counties of West Virginia. Each of these techniques and its estimated results are presented below.

\section{Non-parametric testing for $\sigma$-convergence}

The first concept of convergence examined is unconditional convergence. Sala-iMartin (199.6) posits that using the standard deviation as the measure of dispersion qualifies unconditional convergence as $\sigma$-convergence. The concept of unconditional convergence describes how income distribution among regions evolves over time. If the 
coefficient of variation for a given variable (e.g., per capita real income) decreases over time, the regions in question have converged (Barro and Sala-i-Martin, 1995). On the other hand, if per capita real income in all regions has increased, convergence in this sense means that the poorer regions have grown faster than the initially rich ones (Sala-i-Martin, 1996).

To test for $\sigma$-convergence, the data are separated by 10-year periods: 1969,1979 , 1989, and 1998. The mean values are calculated for each year and are used to determine the multiplier, which is required to convert all the data to an index based on a mean of 100. By doing so, it is possible to retain the original variation and proportionality in the data while at the same time allowing changes in the dependent variables to be examined from a common reference point over time (Nixon, 1997). Having standardized the data for each of the years, the standard deviation is then calculated and used in trend analysis to determine the presence, or otherwise, of $\sigma$-convergence.

Empirical Results - The estimated $\sigma$-convergence for the southern region and Eastern Panhandle counties is presented in Figure 1 and Table 1. In Figure 1, the trends of the three per capita real income indexes confirm the findings of previous studies (Persson, 1994; Drennan and Tobier, 1996; Barro and Sala-i-Martin, 1990, 1991), that is, there was divergence in incomes in the 1980s.

Though there was no data for the period before 1969, the available data suggest that it was not until the early 1980s that the dispersion indexes showed a continuous declining trend. Overall, the estimated dispersion as indicated by the standard deviation (Table 1) shows that the dispersion of per capita personal real income (PI) fell from 0.10 in 1969 to 0.030 in 1998; and that the dispersion of disposable income (PDI) and personal income minus government transfers (PIT) fell from 0.194 to 0.016; and 0.166 to 0.036 , respectively. Barro and Sala-i-Martin (1995) argue that $\sigma$-convergence would be observed if "...the dispersion of per capita real income across a group of economies tends to fall over time." Thus, the results in Table 1 show evidence of $\sigma$-convergence. The results imply that per capita real incomes in the southern counties moved closer to income levels in the Eastern Panhandle counties. Note however, that the observed fall in the standard deviations is not monotonic over time since the dispersion increases during the 1970s (Figure 1). 
Figure 1: Sigma Convergence for Per Capita Income 1969-1998.

*Dispersion of logarithm of real per capita incomes in 1997 prices (21 counties).

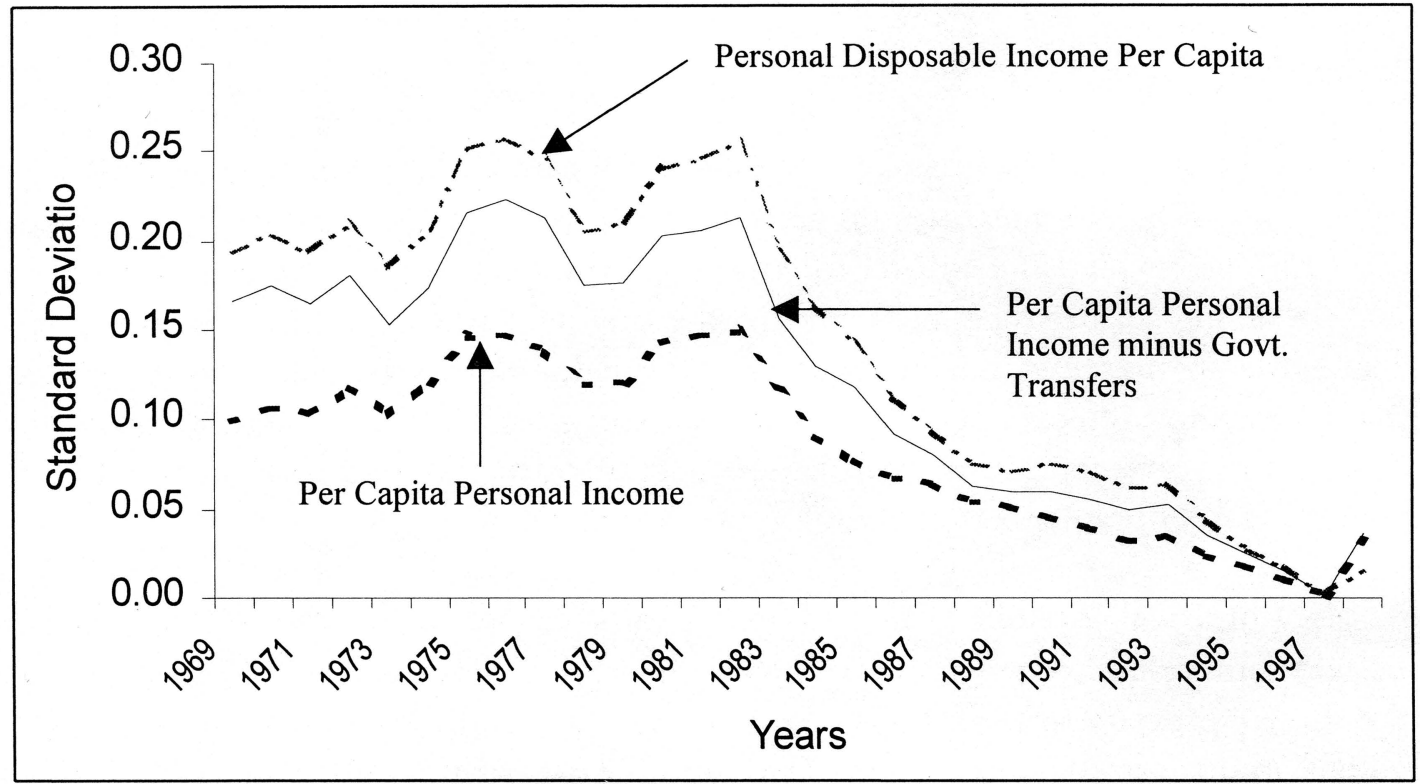

The tests of the means of per capita real incomes for the southern and Eastern Panhandle counties, as well as the $\sigma$-convergence for the sub-periods are reported in Table 1 . The results suggest that since 1969, per capita real incomes for the southern and Eastern Panhandle counties show increasing trends. The estimated mean index for per capita personal real income in the southern counties increased from 14.47 in 1969 to 96.69 in 1998, whereas the mean index for the Eastern Panhandle counties increased from 13.8 to 97.15. The mean indexes for disposable real income per capita and personal real income minus government transfer per capita, also increased in both regions. An interesting observation from Table 1 is that until the 1980s, mean indexes of per capita real incomes for the southern counties were higher than mean indexes of per capita real incomes for the Eastern Panhandle counties. However, this trend was reversed starting in the 1980s. 


\section{Table 1: Test of Equality of Means among Income Series and Estimates of Sigma Convergence for the Study Areas.}

\section{Southern $W V$ Counties}

\author{
Eastern Panhandle Southern \& Eastern \\ Counties
}

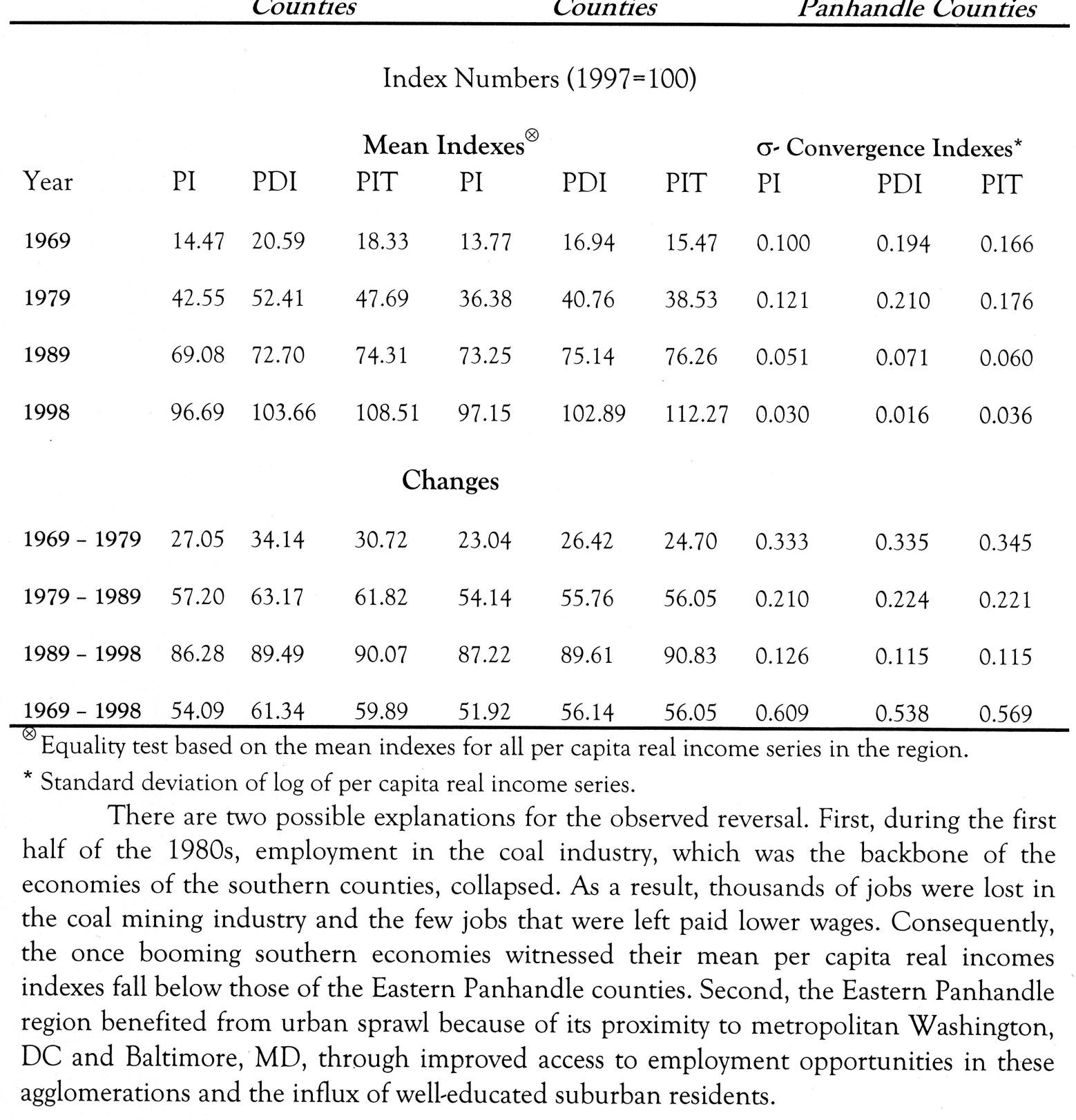

\section{Correlation Analysis}

Simple correlation coefficients within different sub-periods of the total sample can be used to test the concept of convergence over time between variables separated by space (Stigler and Sherwin, 1985). However, since correlation may not be instantaneous but instead may be dynamic, it is also important to examine cross-correlations with a lag structure between the variables of interest. For instance, several studies have examined the 
geographical relationship between prices by looking at correlation coefficients (Lele, 1967; Southworth, Jones, and Pearson, 1979; Timmer, Falcon, and Pearson, 1983; Stigler and Sherwin, 1985; Bukenya and Labys, 2000). Simple correlation coefficients, $r_{i}^{2}$, within different sub-periods of the total sample are calculated for PI, PIT and PDI indexes. The estimated correlation coefficients are then used to estimate the convergence indexes, $b_{i j}$ and $b_{i T}$ for the three indexes, where $i$ represents a county, $j$ a region, and $T$ represents the number of sub-periods of the total sample:

$$
b_{i j}=\frac{r_{12}^{2}+r_{13}^{2}+r_{14}^{2}+\ldots+r_{2021}^{2}}{n_{c_{2}}}
$$

where $i=1, \ldots, 21$ and $j=1,2,3$.

$$
b_{i T}=\frac{\frac{r_{12}^{2}+r_{13}^{2}+r_{14}^{2}+\ldots+r_{2021}^{2}}{n_{c_{2}}}}{\frac{r_{12}^{2}+r_{13}^{2}+r_{14}^{2}+\ldots+r_{2021}^{2}}{n_{c_{2}}}}=\frac{b_{i j}}{C_{1}}
$$

where $\mathrm{T}=1,2, \ldots, 6$ and $\mathrm{c}_{\mathrm{i}}=\mathrm{b}_{\mathrm{ij}}$ for the first sub-period.

In the above equations, a coefficient of $b$ equal to 1 , would represent a perfect transmission of income shock, while a coefficient of zero would represent a short-run invariance to changes in incomes elsewhere. Since the short-run effect is in principle unrestricted, a value $b_{i T}>1$ suggests an over-reaction to changes in income in the current period.

Empirical Results - The results (based on correlation coefficients) for the PI, PIT and PDI indexes are presented in Tables 2, 3 and 4. The graphical representation of the estimated $b_{i j}$ convergence indexes for the southern and Eastern Panhandle counties are shown in Figures 2, 3 and 4. The estimated results show evidence of income instability within the sub-periods. The possible explanations for the observed trends, especially during the 1980s, are factors such as exogenous shocks (i.e., oil price shocks of 1974, 1978, 1981, 1991) and national business cycle conditions (i.e., recession/ depression).

In all three series there is a wider dispersion in per capita disposable personal income (PDI) between the two regions compared to the other two series indicating the influence of personal direct taxes in determining the presence or absence of convergence (Figure 4). In general, correlation coefficients themselves are not capable of detecting the convergence that might have taken place. 
Table 2: Estimated Convergence Index (PI)

\begin{tabular}{|c|c|c|c|c|}
\hline Years & Index & $\begin{array}{l}\text { Southern } \\
\text { Region }\end{array}$ & $\begin{array}{c}\text { Eastern Panhandle } \\
\text { Region } \\
\end{array}$ & $\begin{array}{c}\text { Southern and Eastern } \\
\text { Panhandle Regions }\end{array}$ \\
\hline \multicolumn{5}{|l|}{$1969-1973$} \\
\hline & $b_{i j}$ & 0.985 & 0.987 & 0.979 \\
\hline & $\mathrm{b}_{\text {т }}$ & 1.000 & 1.000 & 1.000 \\
\hline \multicolumn{5}{|l|}{$1974-1978$} \\
\hline & $b_{i j}$ & 0.975 & 0.992 & 0.969 \\
\hline & $\mathrm{b}_{\text {T }}$ & 0.990 & 1.005 & 0.989 \\
\hline \multicolumn{5}{|l|}{$1979-1983$} \\
\hline & $b_{i j}$ & 0.963 & 0.962 & 0.938 \\
\hline & $\mathrm{b}_{\text {T }}$ & 0.978 & 0.975 & 0.958 \\
\hline \multicolumn{5}{|l|}{$1984-1988$} \\
\hline & $b_{i j}$ & 0.784 & 0.981 & 0.853 \\
\hline & $\mathrm{b}_{\mathrm{T}}$ & 0.796 & 0.994 & 0.871 \\
\hline \multicolumn{5}{|l|}{$1989-1993$} \\
\hline & $b_{i j}$ & 0.983 & 0.965 & 0.967 \\
\hline & $\mathrm{b}_{\text {T }}$ & 0.998 & 0.978 & 0.988 \\
\hline \multicolumn{5}{|l|}{$1994-1998$} \\
\hline & $b_{i j}$ & 0.982 & 0.989 & 0.975 \\
\hline & $\mathrm{b}_{\text {т }}$ & 0.997 & 1.002 & 0.996 \\
\hline \multicolumn{5}{|l|}{$1969-1998$} \\
\hline & $b_{i j}$ & 0.995 & 0.993 & 0.988 \\
\hline & $\mathrm{b}_{\text {T }}$ & 1.010 & 1.006 & 1.009 \\
\hline Number of Counties & & 13 & 8 & 21 \\
\hline
\end{tabular}

Figure 2: Estimated Convergence Index for PI

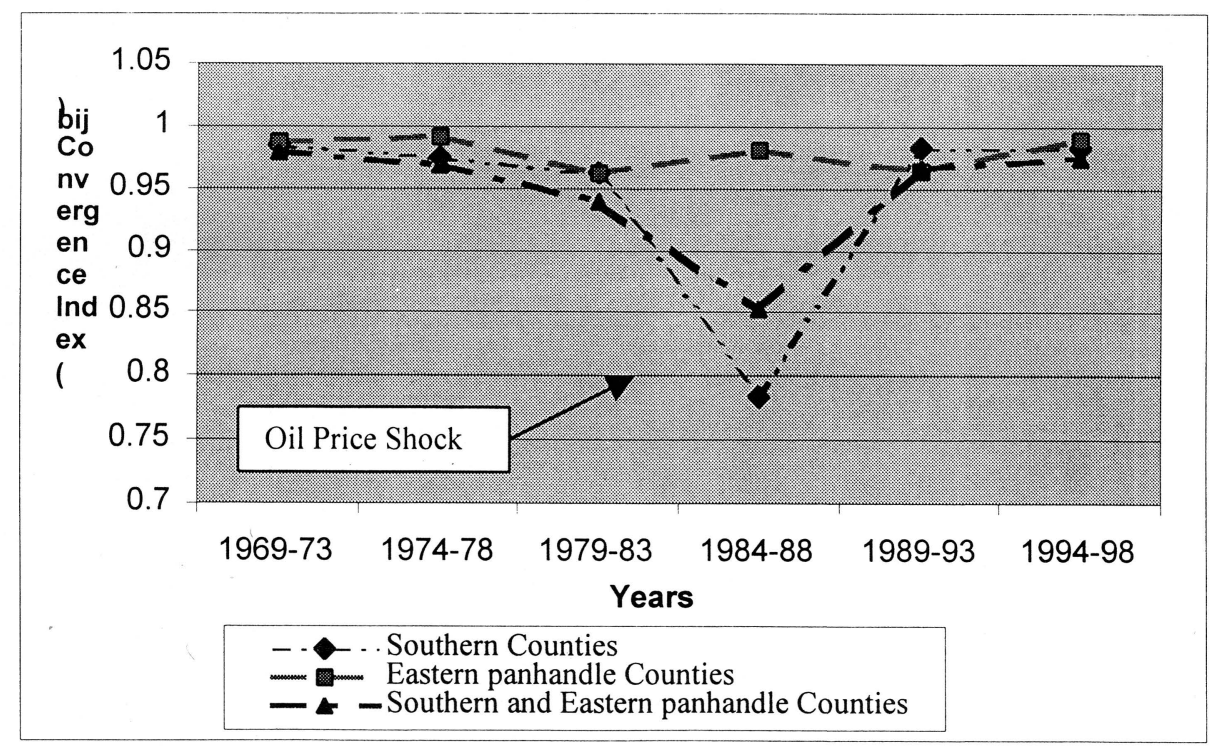


Table 3: Estimated Convergence Index (PIT)

\begin{tabular}{lcccc}
\hline Years & Index & $\begin{array}{c}\text { Southern } \\
\text { Region }\end{array}$ & $\begin{array}{c}\text { Eastern Panhandle } \\
\text { Region }\end{array}$ & $\begin{array}{c}\text { Southern and Eastern } \\
\text { Panhandle Regions }\end{array}$ \\
\hline $1969-1973$ & & & & \\
& $b_{i j}$ & 0.961 & 0.981 & 0.960 \\
$1974-1978$ & $b_{T}$ & 1.000 & 1.000 & 1.000 \\
& & & & 0.944 \\
$1979-1983$ & $b_{i j}$ & 0.954 & 0.986 & 0.983 \\
& $b_{T}$ & 0.993 & 1.005 & 0.809 \\
$1984-1988$ & $b_{i j}$ & 0.874 & 0.902 & 0.843 \\
& $b_{T}$ & 0.909 & 0.919 & 0.744 \\
$1989-1993$ & $b_{i j}$ & 0.626 & 0.972 & 0.775 \\
& $b_{T}$ & 0.651 & 0.991 & 0.892 \\
$1994-1998$ & & & & 0.929 \\
& $b_{i j}$ & 0.929 & 0.897 & 0.964 \\
$1969-1998$ & $b_{T}$ & 0.967 & 0.914 & 1.004 \\
& & & & 0.976 \\
& $b_{i j}$ & 0.963 & 0.986 & 1.017 \\
& $b_{T}$ & 1.002 & 1.005 & 21 \\
\hline
\end{tabular}

Figure 3: Estimated Convergence Index for PIT

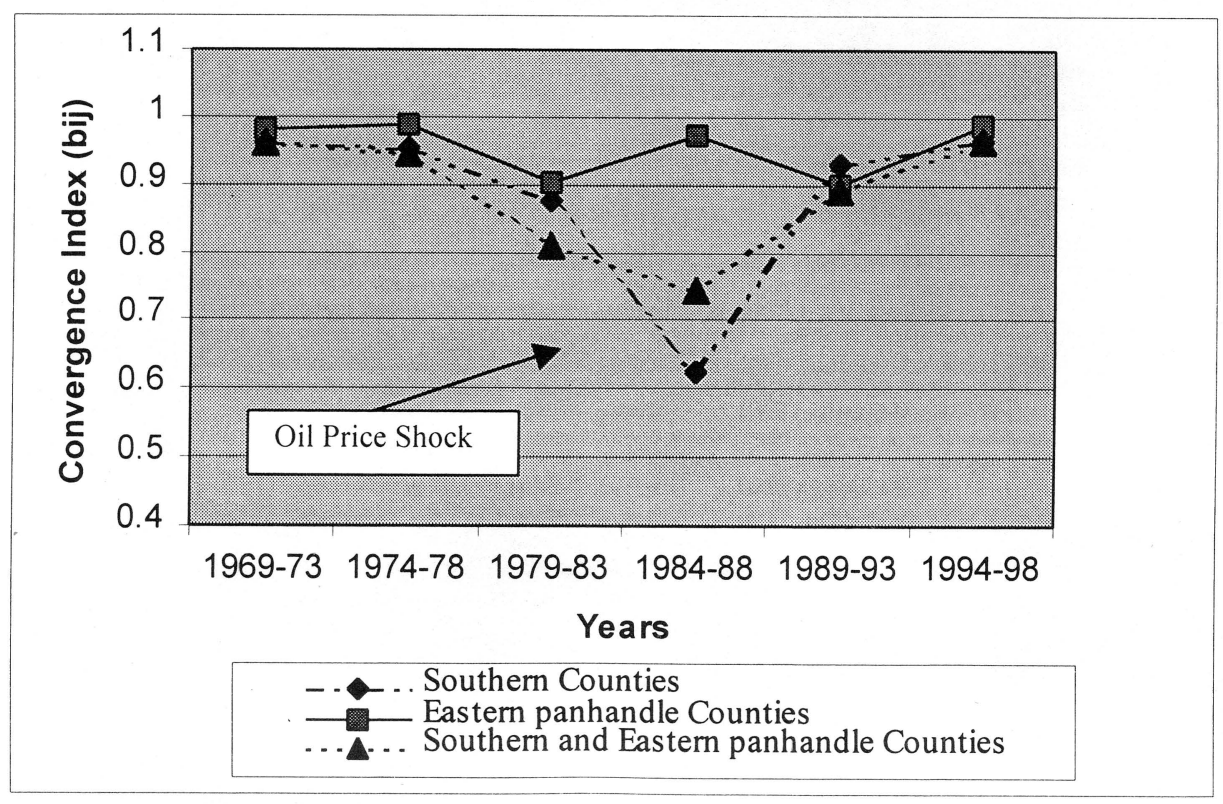


Table 4: Estimated Convergence Index (PDI)

\begin{tabular}{|c|c|c|c|c|}
\hline Years & Index & $\begin{array}{l}\text { Southern } \\
\text { Region }\end{array}$ & $\begin{array}{c}\text { Eastern Panhandle } \\
\text { Region }\end{array}$ & $\begin{array}{l}\text { Southern and Eastern } \\
\text { Panhandle Regions }\end{array}$ \\
\hline \multicolumn{5}{|l|}{$1969-1973$} \\
\hline & $b_{i j}$ & 0.955 & 0.977 & 0.954 \\
\hline & $\mathrm{B}_{\mathrm{T}}$ & 1.000 & 1.000 & 1.000 \\
\hline \multicolumn{5}{|l|}{$1974-1978$} \\
\hline & $b_{i j}$ & 0.733 & 0.564 & 0.546 \\
\hline & $\mathrm{B}_{\mathrm{T}}$ & 0.768 & 0.577 & 0.572 \\
\hline \multicolumn{5}{|l|}{$1979-1983$} \\
\hline & $b_{i j}$ & 0.493 & 0.953 & 0.646 \\
\hline & $\mathrm{B}_{\mathrm{T}}$ & 0.516 & 0.975 & 0.677 \\
\hline \multicolumn{5}{|l|}{$1984-1988$} \\
\hline & $b_{i j}$ & 0.917 & 0.877 & 0.874 \\
\hline & $\mathrm{b}_{\mathrm{T}}$ & 0.960 & 0.898 & 0.916 \\
\hline \multicolumn{5}{|l|}{$1989-1993$} \\
\hline & $b_{i j}$ & 0.843 & 0.815 & 0.823 \\
\hline & $\mathrm{b}_{\mathrm{T}}$ & 0.883 & 0.834 & 0.863 \\
\hline \multicolumn{5}{|l|}{$1994-1998$} \\
\hline & $b_{i j}$ & 0.964 & 0.983 & 0.959 \\
\hline & $\mathrm{b}_{\text {т }}$ & 1.009 & 1.006 & 1.005 \\
\hline \multicolumn{5}{|l|}{$1969-1998$} \\
\hline & $b_{i j}$ & 0.955 & 0.977 & 0.954 \\
\hline & $\mathrm{b}_{\mathrm{T}}$ & 1.000 & 1.000 & 1.000 \\
\hline Number of Counties & & 13 & 8 & 21 \\
\hline
\end{tabular}

Figure 4: Estimated Convergence Index for PDI

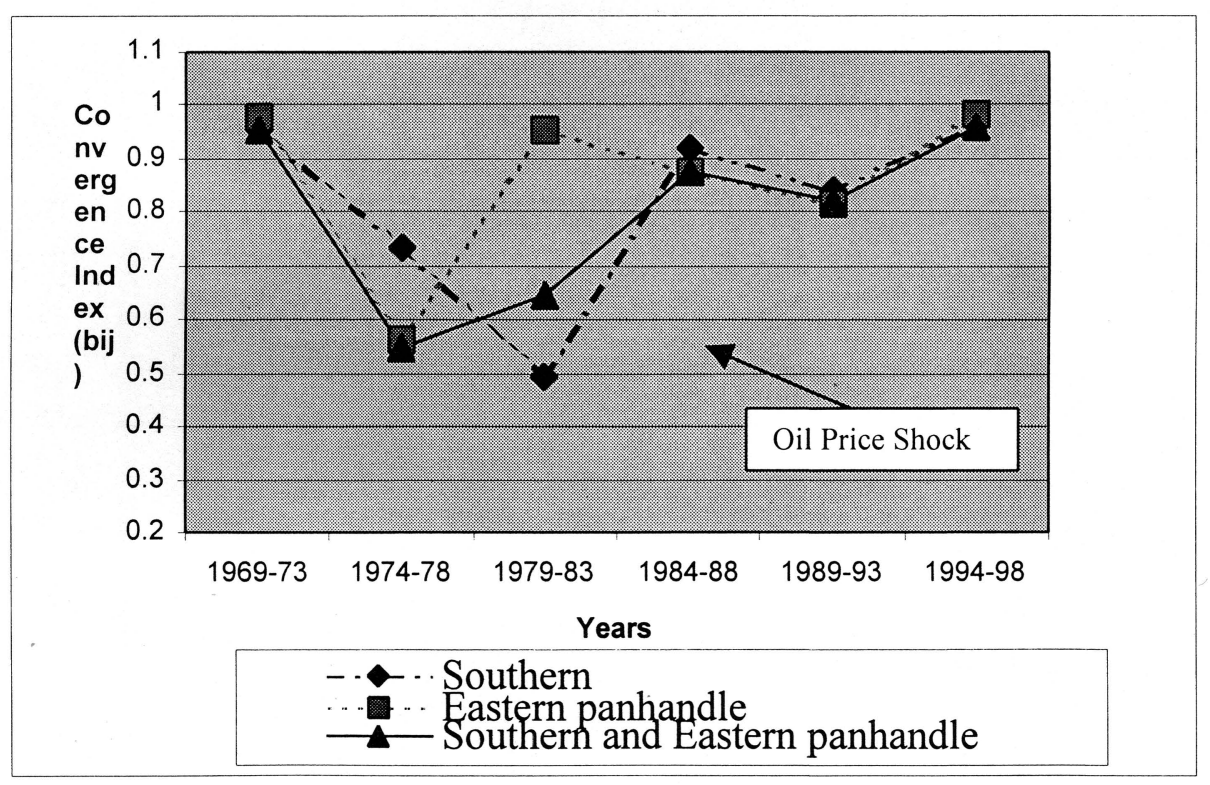




\section{F-test for Convergence}

To further examine convergence in per capita real incomes, the F-test is used to test the null hypothesis, $H_{0}: \sigma_{69}^{2} \leq \sigma_{98}^{2}$ (i.e., the standard deviation of per capita income in the intial year is less or equal to the standard deviation in the later year) against the alternative hypothesis, $H_{A}: \sigma_{69}^{2}>\sigma_{98}^{2}$ (i.e., the standard deviation of per capita income in the initial year is greater than the standard deviation in the later year) at the $\alpha=5 \%$ level of significance. The statistic of this one-sided test is calculated by dividing the variance of one sample by the variance of a second sample as follows: F-test $=S_{69}^{2} / S_{98}^{2}$, where $S_{69}^{2}$ is the standard deviation squared for 1969 of observations $\mathrm{n}=21$, and $S_{98}^{2}$ is the standard deviation squared for 1998 of observations $\mathrm{n}=21$. The null hypothesis is rejected if $F>F(n-1, \alpha)$.

Empirical Results - The results of the F-test are presented in Table 5. They indicate that the null hypothesis, $H_{0}: \sigma_{69}^{2} \leq \sigma_{98}^{2}$, can be rejected in each of the three index series: PI, PDI and PIT. These results provide statistically significant evidence that convergence occurred between 1969 and 1998 within the three types of per capita real incomes between the southern West Virginia and Eastern Panhandle counties.

Table 5: F-test Results

\begin{tabular}{lll}
\hline Hypothesis & F-test Statistics \\
\hline Southern Region and Eastern Panhandle Counties & \\
Null Hypothesis: $H_{0}: \sigma_{69}^{2} \leq \sigma_{98}^{2}$ & PI & $11.11^{*}$ \\
Against & PDI & $147^{*}$ \\
Alternative Hypothesis: $H_{A}: \sigma_{69}^{2}>\sigma_{98}^{2}$ & PIT & $21.26^{*}$ \\
$\mathrm{~N}=21$ & & \\
\hline
\end{tabular}

Patterns similar to those in West Virginia are observed in other U.S. states (Barro and Sala-i-Martin, 1992a) and among Swedish counties in the 1920s (Persson, 1994). To explain such patterns, other than with diminishing returns to capital and technological diffusion, Barro and Sala-i-Martin (1992a) mentioned rapidly falling agricultural prices that adversely affected the relatively poor agricultural states; while Persson (1994) explained the pattern observed among Swedish counties with trade union behavior, central government policies and migration. In this study, the alternative explanation for the observed pattern in the county data is the collapse of the mining industry, which was a major source of income in West Virginia, especially in the southern counties.

\section{Time Series Analysis}

In analyzing the evolution of income disparities using time series data, the most intricate problem is related to structural breaks that may be present in time series. As has been shown by Perron (1989), the presence of a unit root in a time series indicates that the 
series is trend-stationary and contains a small number of structural breaks, or that the true data generating process is characterized by a random walk. A graphical representation of the data series (Figure 1) reveals the presence of breaks and permanent shocks in the time series indexes (PI, PIT and PDI). It is for this reason that in this analysis, the deterministic time-trend hypothesis put forward by Helliwell (1994) is jointly tested with the hypothesis of unit roots and drift, by using augmented Dickey-Fuller tests (ADF) and Phillips-Perron unit root tests (PP) for the three dispersion indexes.

The ADF and PP tests are carried out by estimating an equation with $Y_{t-1}$ subtracted from both sides of the equations:

$$
\Delta Y_{t}=\mu+\gamma Y_{t-1}+\varepsilon_{t}
$$

where $\mu$ and $\gamma$ are parameters and $\varepsilon_{r}$ is assumed to be white noise. $Y$ is a stationary series if $1<\gamma<1$. If $\gamma=1$, y is a nonstationary series (a random walk with drift); if the process is started at some point, the variance of $y$ increases steadily with time and goes to infinity. If the absolute value of $\gamma$ is greater than one, the series is explosive. Therefore, the hypothesis of a stationary series is evaluated by testing whether the absolute value of $\gamma$ is strictly less than one. Both the ADF and the PP tests take the unit root as the null hypothesis $\gamma=1$. Since explosive series do not make economic sense, the null hypothesis is tested against the onesided alternative: $\gamma<1$.

It is worth noting that the ADF and PP tests use different methods to control for higher-order serial correlation in the series. The ADF test makes a parametric correction for higher-order correlation by assuming that the y series follows an $\operatorname{AR}(\gamma)$ process and adjusting the test methodology. The PP test is a nonparametric method of controlling for higher-order serial correlation in a series. While the ADF test corrects for higher order serial correlation by adding lagged differenced terms on the right-hand side, the PP test makes a correction to the t-statistic of the $\gamma$-coefficient from the $A R(1)$ regression to account for the serial correlation in $\varepsilon$. In addition to time series analysis, the study also used the cross-section nature of the data to further examine the disparities in income by conducting parametric tests.

Empirical Results - The results of the ADF and PP tests are presented in Tables 6 and 7 for the 1969 to 1984, and 1984 to 1998 periods, respectively. First, for the 1969. 1984 period (Table 6), the ADF tests on the three index series indicate that they are nonstationary, and the joint tests suggest that the null hypothesis of a unit root, zero drift and no trend cannot be rejected at the $5 \%$ critical value. For the same period, the PP test results are slightly ambiguous. The null hypothesis that a random walk process generates the levels of each of the three-index series of PI, PDI and PIT cannot be rejected. The joint hypothesis of a unit root can be rejected at the 5 percent level for the first differences in each of the three index series, when a time trend is not included in the regression. Overall, the time series results suggest that the null hypothesis of no $\sigma$-convergence cannot be rejected for the 1969-1984 period. 
Table 6: Unit Root Tests (1969-84)

\begin{tabular}{llllllc}
\hline Null Hypothesis & & \multicolumn{2}{c}{$\begin{array}{c}\text { ADF } \\
\text { Test Statistics }\end{array}$} & & $\begin{array}{c}\text { PP } \\
\text { Test Statistics }\end{array}$ & $\begin{array}{c}\oplus \text { Critical } \\
\text { Value: } 5 \%\end{array}$ \\
\hline & & Levels & 1* Differences & Levels & 1* Differences & \\
Constant no Trend & PI & -1.306 & -1.909 & -0.815 & -2.544 & -3.08 \\
$H_{0}: \gamma=0$ & PDI & -1.853 & -2.393 & -1.273 & -2.797 & \\
T-Test & PIT & -1.539 & -2.180 & -1.062 & -2.807 & \\
F-Test & & & & & & \\
& PI & 1.298 & 2.902 & 0.125 & $6.517^{*}$ & \\
& PDI & 1.969 & 4.004 & 0.929 & $7.981^{*}$ & \\
Constant with Trend & PIT & 1.419 & 3.688 & 0.500 & $7.979^{*}$ & -3.76 \\
$H_{0}: \gamma=0$ & PI & -0.639 & -2.826 & -0.176 & -3.214 & \\
T-Test & PDI & -1.385 & -2.900 & -0.874 & -3.147 & \\
& PIT & -1.137 & -2.763 & -0.741 & -3.188 & \\
F-Test & & & & & & \\
& PI & 1.434 & 4.064 & 1.414 & 5.336 & \\
& PDI & 1.422 & 3.882 & 1.463 & 5.093 & \\
& PIT & 1.224 & 3.840 & 1.370 & 5.210 & \\
\hline
\end{tabular}

${ }^{*}$ Denotes rejection of the hypothesis

$\oplus$ Denotes MacKinnon (1991) critical values for unit root tests

Table 7: Unit Root Tests (1984-98)

\begin{tabular}{|c|c|c|c|c|c|c|}
\hline \multirow[t]{2}{*}{ Null Hypothesis } & & \multicolumn{2}{|c|}{$\begin{array}{c}\text { ADF } \\
\text { Test Statistics }\end{array}$} & \multicolumn{2}{|c|}{$\begin{array}{c}\text { PP } \\
\text { Test Statistics } \\
\end{array}$} & \multirow[t]{2}{*}{$\begin{array}{l}\oplus \text { Critical } \\
\text { Value: } 5 \% \\
\end{array}$} \\
\hline & & Levels & 1* Differences & Levels & 1st Differences & \\
\hline Constant no Trend & PI & -1.747 & -1.463 & -2.240 & $-3.647^{*}$ & -3.08 \\
\hline$H_{0}: \gamma=0$ & PDI & -1.621 & -3.081 & -2.064 & $-6.216^{*}$ & \\
\hline T-Test & PIT & -1.579 & -1.744 & -2.061 & $-3.378^{*}$ & \\
\hline \multirow[t]{3}{*}{ F-Test } & PI & 2.751 & $7.227^{*}$ & $5.699^{*}$ & $12.911^{*}$ & \multirow[t]{3}{*}{4.03} \\
\hline & PDI & 2.357 & $21.012^{*}$ & $5.003^{*}$ & $36.339^{*}$ & \\
\hline & PIT & 2.366 & 4.026 & $4.846^{*}$ & $11.521^{*}$ & \\
\hline \multirow{3}{*}{$\begin{array}{l}\text { Constant with Trend } \\
H_{0}: \gamma=0 \\
\text { T-Test }\end{array}$} & PI & -0.893 & -1.871 & -1.127 & $-3.940^{*}$ & \multirow[t]{3}{*}{-3.76} \\
\hline & PDI & -1.896 & -2.831 & -2.097 & $-5.826^{*}$ & \\
\hline & PIT & -0.306 & -2.241 & -0.928 & $-3.813^{*}$ & \\
\hline \multirow[t]{3}{*}{ F-Test } & PI & 1.813 & $5.382^{*}$ & 2.686 & $8.331^{*}$ & \multirow[t]{3}{*}{5.34} \\
\hline & PDI & 2.713 & $13.748^{*}$ & 4.428 & $20.135^{*}$ & \\
\hline & PIT & 1.453 & 4.963 & 2.246 & $7.574^{*}$ & \\
\hline
\end{tabular}

* Denotes rejection of the hypothesis.

$\oplus$ Denotes MacKinnon (1991) critical values for unit root tests 
The 1984-98 results indicate that the null hypothesis that a random walk process generates the level series of PI, PID and PIT cannot be rejected. However, all the tests suggest that the joint unit root, zero drift and no trend null hypothesis for the first differences series cannot be rejected at the 5\% critical level for PIT, but are rejected at the same critical level for the first differences series for PDI and PI. These results suggest that the null hypothesis of no $\sigma$-convergence cannot be rejected for the 1984-1998 period for PIT, while it is rejected for PDI and PI. Thus, transfers appear to have played a significant role in determining convergence.

\section{Parametric Testing for $\beta$-Convergence}

For parametric testing, the speed of convergence, $\beta$, is estimated. This approach has been widely used in recent empirical studies on growth (Barro, 1991; Baumol, 1986; Mankiw, Romer and Weil, 1992). $\beta$-convergence would be observed if, in a cross-section data set, economic units that are initially poor tend to grow faster than rich units. If the $\beta$ coefficient is estimated without taking into account the characteristics that determine the steady state of the economy-such as the savings rate, technology and institutions-it is then referred to as absolute convergence. The conditional convergence hypothesis, on the other hand, refers to cases where differences in steady states are contemplated. For example, two economies might have different savings rates, reflecting differences in rates of time preference. In this case, the standard neo-classical framework predicts that the two economies will enjoy the same steady-state growth rate, but the one with a higher savings rate will have a higher steady-state income per capita (Nixon, 1997).

The analysis of $\beta$-convergence in this chapter follows the methodology suggested by Sala-i-Martin (1996):

$$
\begin{aligned}
& \frac{1}{T} \log \left(\frac{y_{i, t}}{y_{i, t-T}}\right)=\alpha_{1}-\left(\frac{1-e^{-\beta_{1} T}}{T}\right) * \log \left(y_{i, t-T}\right)+u_{i} \\
& \frac{1}{T} \log \left(\frac{y_{i, t}}{y_{i, t-T}}\right)=\alpha_{2}-\left(\frac{1-e^{-\beta_{2} T}}{T}\right) * \log \left(y_{i, t-T}\right)+\delta_{1} A G R_{i, t}+\delta_{2} I N D_{i, t}+\delta_{3} M I G_{i, t}+u_{i}
\end{aligned}
$$

where $y_{i, t}$ is real per capita income in region $i$ at time t, $T$ is the length of the interval, $\alpha_{i}$ is the intercept, $\beta_{i}(i=1,2)$ is the rate of convergence parameter, $\delta_{i}$ are linear parameters and $u_{i}$ is the disturbance term.

If regions with initially lower per capita real income, $y_{i, t-T}$, grow faster than regions with higher per capita real income, then $\beta>0$, and there is convergence. This methodology is based on the assumption that the comparison between the growth rates of any two regions/counties during the same sub-period provides the same information, as does a comparison between the growth rates of the same regions/counties during two sub-periods. In both cases, convergence implies that a (relatively) poorer region/county should grow at a faster rate than a (relatively) richer one.

Empirical Results The results of the regressions are presented in Tables 8, 9 and 10. The results indicate that the models explain the process of convergence relatively well (Adjusted R-squares range between 83 to 94 percent). Based on these results, the southern 
and Eastern Panhandle counties experienced $\beta$-convergence between 1969-1985 and between 1985-1998. These results imply that the poor counties were catching up to the rich ones at a rate between 1.8 and 2.4 percent annually, based on PI and PIT indexes and at a rate between 1.9 and 2.1 percent based on the PDI index. Therefore, the null hypothesis of no convergence ${ }^{3}$ can be rejected at the one percent critical level. The estimated speed of convergence is much slower for PDI than for PI and PIT after 1985. The test of stability of the $\beta$-coefficients for the models suggests that there was no change in the process of convergence between the period 1969-1985 and 1985-1998. The inclusion of the control variables in model 1A affects the adjusted R-squares marginally. That is to say, convergence among counties before 1985 was mostly a function of the counties' initial per capita real incomes. For the period after 1985, model 1B, the inclusion of the control variables is more important as the adjusted R-squares increase from 0.84 to 0.92 for $\mathrm{PI}$, 0.83 to 0.90 for PDI and 0.83 to 0.92 for PIT. This suggests that the rate of migration and the employment structure of the regions largely influence the speed of convergence in per capita real income.

\footnotetext{
${ }^{3}$ The divergence in per capita incomes observed in the 1980s, in the previous section, is not manifested here because the 1980s period is divided between the two sub-periods (i.e., 1969-85 and 1985-98).
} 
Table 8: Regression Models for Per Capita Real Personal Income (PI)

\begin{tabular}{|c|c|c|c|c|c|}
\hline MODEL & \multicolumn{2}{|c|}{$1 \mathrm{~A}$} & \multicolumn{2}{|c|}{$1 \mathrm{~B}$} & 2 \\
\hline Period & \multicolumn{2}{|c|}{$1969-85$} & \multicolumn{2}{|c|}{$1985-98$} & $1969-98$ \\
\hline Equation & (i) & (ii) & (i) & (ii) & (ii) \\
\hline Constant & $\begin{array}{l}0.1876 \\
(2.042)\end{array}$ & $\begin{array}{c}0.260 \\
(2.681)\end{array}$ & $\begin{array}{c}0.185 \\
(4.193)\end{array}$ & $\begin{array}{c}0.254 \\
(3.810)\end{array}$ & $\begin{array}{c}0.244 \\
(2.556)\end{array}$ \\
\hline$\beta$ & $\begin{array}{l}0.018^{*} \\
(4.95)\end{array}$ & $\begin{array}{l}0.022^{*} \\
(3.72)\end{array}$ & $\begin{array}{c}0.019^{*} \\
(4.88)\end{array}$ & $\begin{array}{l}0.024^{*} \\
(3.50)\end{array}$ & $\begin{array}{l}0.018^{*} \\
(3.82)\end{array}$ \\
\hline AGRICULTURE & $m$ & $\begin{array}{c}-0.004 \\
(-0.681)\end{array}$ & $m$ & $\begin{array}{c}-0.004 \\
(-0.104)\end{array}$ & $\begin{array}{c}-0.004 \\
(-0.064)\end{array}$ \\
\hline INDUSTRY & - & $\begin{array}{c}-0.003^{* *} \\
(-2.55)\end{array}$ & $m$ & $\begin{array}{c}-8.77 \mathrm{E}-02^{*} \\
(-2.58)\end{array}$ & $\begin{array}{c}-0.003^{*} \\
(-3.55)\end{array}$ \\
\hline MIGRATION & - & $\begin{array}{c}0.32^{* * *} \\
(1.56)\end{array}$ & $m$ & $\begin{array}{l}0.27^{* *} \\
(2.11)\end{array}$ & $\begin{array}{c}0.039^{* *} \\
(1.91)\end{array}$ \\
\hline Observation & 21 & 21 & 21 & 21 & 21 \\
\hline$R^{2}\left(R_{a d j}^{2}\right)$ & $0.90(0.88)$ & $0.92(0.90)$ & $0.86(0.84)$ & $0.93(0.92)$ & $0.88(0.85)$ \\
\hline Test of $\beta$-stability & $\chi^{2}=1.51$ & $\chi^{2}=0.66$ & & & \\
\hline
\end{tabular}

Note: t-statistics in parentheses.

${ }^{*},{ }^{* *}$, and ${ }^{* * *}$ indicate significance at 1,5 and $10 \%$, respectively using a two-tailed test.

The regressions use non-linear regression to estimate the models. For models $1 \mathrm{a}$ and $1 \mathrm{~b}$ the estimation method is SUR. The test of $\beta$-stability tests (using a Wald-test) the hypothesis that the $\beta$ in model 1a equals the $\beta$ in model $1 \mathrm{~b}$. 
Table 9: Regression Models for Per Capita Real Disposable Income (PDI)

\begin{tabular}{|c|c|c|c|c|c|}
\hline MODEL & \multicolumn{2}{|c|}{$1 \mathrm{~A}$} & \multicolumn{2}{|c|}{$1 \mathrm{~B}$} & 2 \\
\hline Period & \multicolumn{2}{|c|}{ 1969-85 } & \multicolumn{2}{|c|}{ 1985-98 } & 1969-98 \\
\hline Equation & (i) & (ii) & (i) & (ii) & (ii) \\
\hline Constant & $\begin{array}{c}0.344 \\
(4.802)\end{array}$ & $\begin{array}{c}0.382 \\
(6.832)\end{array}$ & $\begin{array}{c}0.857 \\
(3.162)\end{array}$ & $\begin{array}{c}0.220 \\
(5.813)\end{array}$ & $\begin{array}{c}0.711 \\
(3.226)\end{array}$ \\
\hline$\beta$ & $\begin{array}{l}0.019^{*} \\
(4.94)\end{array}$ & $\begin{array}{l}0.021^{*} \\
(3.71)\end{array}$ & $\begin{array}{l}0.020^{*} \\
(4.88)\end{array}$ & $\begin{array}{l}0.021^{*} \\
(3.50)\end{array}$ & $\begin{array}{l}0.018^{*} \\
(3.82)\end{array}$ \\
\hline AGRICULTURE & $m$ & $\begin{array}{l}-0.009 \\
(-1.02)\end{array}$ & - & $\begin{array}{l}-0.003 \\
(-0.55)\end{array}$ & $\begin{array}{l}-0.001 \\
(-0.17)\end{array}$ \\
\hline INDUSTRY & $m$ & $\begin{array}{c}-0.0003^{*} \\
(-3.77)\end{array}$ & $m$ & $\begin{array}{c}-0.0003^{*} \\
(-3.15)\end{array}$ & $\begin{array}{c}-0.0003^{*} \\
(-2.88)\end{array}$ \\
\hline MIGRATION & 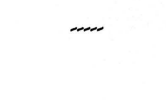 & $\begin{array}{l}0.191^{\star *} \\
(1.755)\end{array}$ & $\ldots$ & $\begin{array}{l}0.23^{* *} \\
(1.75)\end{array}$ & $\begin{array}{c}0.133^{* *} \\
(2.17)\end{array}$ \\
\hline Observation & 21 & 21 & 21 & 21 & 21 \\
\hline$R^{2}\left(R_{a d j}^{2}\right)$ & $0.89(0.87)$ & $0.91(0.90)$ & $0.85(0.83)$ & $0.92(0.90)$ & $0.89(0.86)$ \\
\hline Test of $\beta$-stability & $\chi^{2}=1.54$ & $\chi^{2}=0.76$ & & & \\
\hline
\end{tabular}

Note: t-statistics in parentheses.

${ }^{*},{ }^{* *}$, and ${ }^{* * *}$ indicate significance at 1,5 and $10 \%$, respectively using a two-tailed test.

The regressions use non-linear regression to estimate the models. For models $1 \mathrm{a}$ and $1 \mathrm{~b}$ the estimation method is SUR. The test of $\beta$-stability tests (using a Wald-test) the hypothesis that the $\beta$ in model 1a equals the $\beta$ in model $1 b$. 
Table 10: Regression Models for Per Capita Real Personal Incomes Minus Transfers (PIT)

\begin{tabular}{|c|c|c|c|c|c|}
\hline MODEL & \multicolumn{2}{|c|}{$1 \mathrm{~A}$} & \multicolumn{2}{|c|}{$1 \mathrm{~B}$} & 2 \\
\hline Period & \multicolumn{2}{|c|}{ 1969-85 } & \multicolumn{2}{|c|}{ 1985-98 } & 1969-98 \\
\hline Equation & (i) & (ii) & (i) & (ii) & (ii) \\
\hline Constant & $\begin{array}{l}0.200 \\
(2.89)\end{array}$ & $\begin{array}{l}0.575 \\
(2.93)\end{array}$ & $\begin{array}{l}0.191 \\
(3.53)\end{array}$ & $\begin{array}{l}0.499 \\
(2.43)\end{array}$ & $\begin{array}{l}0.251 \\
(2.87)\end{array}$ \\
\hline$\beta$ & $\begin{array}{l}0.018^{\star} \\
(11.31)\end{array}$ & $\begin{array}{l}0.022^{*} \\
(8.32)\end{array}$ & $\begin{array}{l}0.021^{*} \\
(14.04)\end{array}$ & $\begin{array}{l}0.024^{*} \\
(6.94)\end{array}$ & $\begin{array}{l}0.016^{*} \\
(12.06)\end{array}$ \\
\hline AGRICULTURE & $m$ & $\begin{array}{c}-0.0002 \\
(-0.40)\end{array}$ & $m$ & $\begin{array}{c}-0.0002 \\
(-0.35)\end{array}$ & $\begin{array}{c}-0.003^{\star * *} \\
(-1.75)\end{array}$ \\
\hline INDUSTRY & $m$ & $\begin{array}{c}-0.00018^{*} \\
(-6.22)\end{array}$ & $m$ & $\begin{array}{c}-0.00016^{*} \\
(-5.60)\end{array}$ & $\begin{array}{c}-0.0003^{*} \\
(-2.93)\end{array}$ \\
\hline MIGRATION & - & $\begin{array}{c}0.134^{* * *} \\
(1.49)\end{array}$ & - & $\begin{array}{c}0.201^{* *} \\
(1.70)\end{array}$ & $\begin{array}{c}0.233^{* *} \\
(1.83)\end{array}$ \\
\hline Observation & 21 & 21 & 21 & 21 & 21 \\
\hline$R^{2}\left(R_{a d j}^{2}\right)$ & $0.90(0.89)$ & $0.91(0.90)$ & $0.85(0.83)$ & $0.94(0.92)$ & $0.88(0.85)$ \\
\hline Test of $\beta$-stability & $\chi^{2}=1.53$ & $\chi^{2}=0.79$ & & & \\
\hline
\end{tabular}

Note: t-statistics in parentheses.

${ }^{*},{ }^{* *}$, and ${ }^{* * *}$ indicate significance at 1,5 and $10 \%$, respectively using a two-tailed test.

The regressions use non-linear regression to estimate the models. For models $1 \mathrm{a}$ and $1 \mathrm{~b}$ the estimation method is SUR. The test of $\beta$-stability tests (using a Wald-test) the hypothesis that the $\beta$ in model 1a equals the $\beta$ in model $1 b$. 


\section{Summary and Conclusions}

The studies that we cited have all established that regional income divergence occurred in the 1980s, using either per capita personal income or per capita earnings as the measure of regional income. In this analysis both cross-section and time series data have been employed to reinvestigate this claim and to examine whether the patterns of per capita real income across the southern and Eastern Panhandle regions of West Virginia are consistent with the convergence hypothesis. The study used inflation-adjusted per capita household income as reported by the US Census of Population because the data are available for both regions and because the statistics provide a measure of changes in living standards for typical American households over time.

Cross-section results support the convergence hypothesis, while time series (stationarity test) results are ambivalent. Time series results suggest that the data are nonstationary between 1969 and 1984, implying that there was no $\sigma$-convergence during these periods, but the results show $\sigma$-convergence during the 1984-1998 period. However, $\sigma$-convergence was obtained only in the PDI and PI dispersion indexes. The contradictions between the results of the cross-section and time series analyses, respectively, are not entirely surprising. It has been documented (Baffes and Ajwad, 1998; Hamilton, 1994; Bukenya and Labys, 2000) that conventional stationarity tests exhibit low power and may give misleading results regarding the true degree of cointegration.

With regard to divergence, several possible explanations for the observed divergence trends in the 1980s have been advanced. For instance, Garnick (1990) identified three determinants of regional per capita income growth and divergence for regions: differential regional earnings, the employment to adult population ratio and, less important, industry mix. He argued that any model of income growth must include measures of those factors because earnings reflect the capital to labor ratio, employment to population ratios reflect preferences for work, and income and industry mix reflect differences in marginal productivity across industries.

In their econometric evidence in support of the neoclassical theory of regional growth over the period 1880 to 1988 , Barro and Sala-i-Martin $(1990,1991)$ attribute the observed divergence in the 1920s to shocks to agriculture, which adversely affected belowaverage income regions, and the divergence in the 1980s to oil price shocks. While all these observable facts might explain income divergence, the oil price shock phenomenon seems more fitting for accounting for the divergence in per capita real income of some belowaverage income regions such as West Virginia.

The main objective of the study was to examine the distribution of per capita incomes among the study areas. Both cross-section and time series data were used to test the convergence hypothesis. Several approaches of examining convergence were used: $\sigma$ convergence test, correlation analysis, F-test for convergence, time series analysis and $\beta$ convergence test.

First, the results concurred with the conclusions reached by previous studies that divergence in the 1970s replaced the convergence that was observed in earlier decades. Second, the results showed that the gap in per capita real income between the southern and Eastern Panhandle counties had narrowed after the 1960s, though at a slow rate of 
only about 2 percent per year. Third, the results suggest that the rate of migration and the employment structure of the regions influenced the speed of convergence in per capita real income. Fourth, the data revealed that before the 1980s average per capita real incomes in the southern counties were higher than average per capita real incomes in the Eastern Panhandle counties. However, this trend was reversed during the 1980s. Lastly, the findings showed that there is a wider dispersion in personal disposable income across the counties than in personal income per capita and personal income minus government transfers. The results suggest that the effects of factor mobility and relocation of firms on the convergence process might have reached their limits in reducing regional disparities. From a policy perspective, the results suggest that reductions in personal direct taxes, and increases in government transfers and, possibly, other government assistance programs are the alternative tools for use by policy makers to further close regional gaps. 


\section{References}

Armstrong, H. A. (1995). "Convergence among regions of the European Union, 19501990." Papers in Regional Science, 74 (2): 143-152.

Baffes, J. and M. I. Ajwad. (1998). "Detecting price linkage: Methodological issues and an application to the world market of cotton." Working Paper, Development Economics Research Group. The World Bank, Washington D.C.

Barro, R. J., and X. Sala-i-Martin. (1990). "Economic growth and convergence across the United States." NBER Working Paper Number 3419.

Barro, R. J., and X. Sala-i-Martin. (1991). "Convergence across states and regions." Brookings Papers on Economic Activity: 107-182.

Barro, R. J., and X. Sala-i-Martin. (1992a). “Convergence.” Journal of Political Economy, 100: $223-51$.

Barro, R. J., and X. Sala-i-Martin. (1992b). "Regional growth and migration: A JapanUnited States comparison." Journal of the Japanese and International Economies, 6: 312-346.

Barro, R. J., and X. Sala-i-Martin. (1995). Economic Growth. McGraw-Hill. New York.

Barro, R. J., (1994). "Determinants of economic growth: A cross-country empirical study." NBER Working Paper Number 5698.

Barro, R. J., N. G. Mankiw, and X. Sala-i-Martin. (1995). "Capital mobility in neoclassical models of growth." American Economic Review, 85: 103-15.

Barro, J. Robert. (1997). Determinants of Economic Growth: A Cross-Country Empirical Study Cambridge, MA: MIT Press.

Baumol, W. J. (1986). "Productivity growth, convergence and welfare: What the long-run data show." American Economic Review, 76: 1072-1085.

BBER. (1999). "County data profile." Bureau of Business and Economic Research, West Virginia University. http://www.be.wvu.edu/serve/bureau/online/cdp.htm

BEA. (1999/2000). "State and Local Area data: Local area personal income." Bureau of Economic Analysis. http://www.bea.doc.gov/bea/regional/data.htm.

Bernard, A. B., and S. N. Durlauf. (1991/3). "Convergence in international output." Working Paper 93-7. Department of Economics, MIT Cambridge, MA. 
Bernard, A. B., and S. N. Durlauf. (1994). "Interpreting tests of the convergence hypothesis." University of Wisconsin-Madison, SSRL Working Paper 940 IR.

Bernard, A. and C. Jones. (1996). "Productivity and convergence across US states and industries." Empirical Economics, 21: 113 -135.

BLS. (1999). "State and Metropolitan Areas at a Grace." Bureau of Labor Statistics. http://stats.bls.gov/datahome.htm.

Borts, G. H. (1960). "The equalization of returns and regional economic growth." American Economic Review, 50: 319-347.

Browne, L. E. (1989). "Shifting regional fortunes: the wheel turns." New England Economics Review, May/ June: 27-40.

Bukenya, J. O., and W. C. Labys. (2000). "Price convergence in international commodity markets: fact or fiction?" Working Paper, Morgantown WV: Resource Economics Program, West Virginia University.

Carlino, Gerald A., and S. Edwin Mills. (1987). "The determinants of county growth." Journal of Regional Science, 27 (1): 39-54.

Carlino, G. A. (1992). "Are regional per capita earnings diverging?" Business Review (Federal Reserve Bank of Philadelphia), March/April: 3-12.

Carlino, G. A., and L. O. Mill. (1993). "Are U.S. regional incomes converging? A time series analysis." Journal of Monetary Economics, 32: 335-346.

Chatterji, M., and J. Dewhurst. (1996). "Convergence clubs and relative economic performance in Great Britain." Regional Studies, 30: 31-40.

Cheshire, P., and Carbonaro. (1995). "Convergence in regional growth rates: An empty black box?" In H.W. Armstrong and R. W. Vickerman (eds), Convergence and Divergence among European Regions, European Research in Regional Science. London:Pion.

Cuadrado-Roura, J. R., B. Garcia-Greciano, and J. L. Raymond. (1999). "Regional convergence in productivity and productive structure: The Spanish case." International Regional Science Review, 22: 35 -53.

De la Fuente, A., and X. Vives. (1995). "Infrastructure and education as instruments of regional policy: Evidence from Spain.” Economic Policy, 20: 13-51. 
Drennan, M. P., and E. Tobier. (1996). "The interruption of income convergence and income growth in large cities in the 1980s." Urban Studies, 33 (1): 63-71.

Easterlin, A. Richard. (1960). "Regional growth of income." In S. Kuznets, A. Miller, and R. Easterlin (eds.), Population Redistribution and Economic Growth in the United States, 1870-1950. Philadelphia: American Philosophical Society.

Fingleton, B. (1999). "Estimates of time to economic convergence: An analysis of regions of the European Union." International Regional Science Review, 22: 5 -34.

Garnick, D. H. and H. L. Friedenberg. (1982). "Accounting for regional differences in per capita personal income growth." Survey of Current Business, 62: 24-34.

Garnick, D. H. (1990). "Accounting for regional differences in per capita personal income growth: an update and extension." Survey of Current Business, 70: 29-40.

Hamilton, J. (1994). Time Series Analysis. New Jersey: Princeton University Press.

Helliwell, J. (1994). “Convergence and migration among provinces." PEAP Policy Study Number 94-2. Institute for Policy Analysis. University of Toronto.

Hicks, J. R. (1932). The Theory of Wages. London: Macmillan.

Jeong, W. (1995). "Review and test on the convergence hypothesis: Time series analysis." Advanced Regional Economics Term Paper. Sage University.

Kuznets, Simon. (1955). "Economic growth and income inequality." American Economic Review, 65: 1-28.

Lele, U. (1967). "Market intergration: A study of sorghum prices in western India." Journal of Farm Economics, 49: 149-159.

L'opez-Bazo, E., et al. (1998). "Regional economic dynamics and convergence in the European Union." Annals of Regional Science, 36: 1 -28.

Mankiw, N., D. Romer, and D. N. Weil. (1992). "A contribution to the empirics of economic growth." Quarterly Journal of Economics, 107: 407 -437.

Neven, D and C. Gouyette. (1995). "Regional convergence in the European community." Journal of Common Market Studies, 33 (1): 47-65.

Nixon, John. (1997). "Convergence analysis of health care expenditure in the EU countries using two approaches." Center for Review and Dissemination and Department of Economics and Related Studies. UK: University of York. 
Perloff, H. S. (1963). "How a region grows." New York: Committee for Economic Development.

Perron, P. (1989). "The great crash, the oil price shock and the unit root hypothesis." Econometrica, 57: 1361-1401.

Persson, J. (1994). "Convergence in per capita income and migration across the Swedish counties, 1906-1990.” Institute for International Economic Studies. Stockholm University, Sweden.

Persson, J. (1997). "Convergence across the Swedish counties, 1911-1993." European Economic Review, 41: 1835-1852.

Phelps, E. (1966). Golden Rules of Economic Growth. New York: Norton.

Quah, Danny. (1993). "Galton's fallacy and tests of the convergence hypothesis." Scandinavian Journal of Economics, 95 (4): 427-443.

Quah, D. T. (1996b). "Regional convergence clusters across Europe." European Economic Review, 40: 951 -958.

REIS. (1969-1998). "State and county level variables." Regional Economic Information System. http://fisher.lib.Virginia.EDU/reis/

Rey, S. J., and B. D. Montouri. (1999). "U.S. regional income convergence: A spatial econometric perspective." Regional Studies, 33: 143 -156.

Romer, P. M. (1994). "The origin of endogenous growth." Journal of Economic Perspectives, 8: 3-22.

Sala-i-Martin, X . (1996). "Regional cohesion: Evidence and theories of regional growth and convergence." European Economic Review, 40: 1325-1352.

Sala-i-Martin, X. (1996). "The classical approach to convergence analysis." Economic Journal, 106: 1019-36.

Solow, R. M. (1956). "A contribution to the theory of economic growth." Quarterly Journal of Economics, 70: 65-94.

Southworth, V. R.., W. O. Jones and S. R. Pearson. (1979). "Food crops marketing in Atebubu district Ghana." Food Research Institute Studies, 16: 157-196.

Stigler, G., and R. A. Sherwin. (1985). "The extent of a market." Journal of Law and Economics, 28: 555-585. 
Taylor, Alan M., and Jeffrey G. Williamson. (1994). "Convergence with age of mass migration." NBER, Working Paper Number 4711.

Timmer, C. P., W. P. Falcon and S. R. Pearson. (1983). Food Policy Analysis. Baltimore: Johns Hopkins University Press.

USCB. (1991/2000). "Statistical abstract of the United States." U.S. Census Bureau. Washington, DC: U.S. Government Printing Office.

USCB. (1999). "County population estimates and demographic." U.S. Census Bureau. Http://www.census.gov/population/www/estimates/countypop.html

Williamson, G. Jeffrey. (1992). "The evolution of global markets in the first and second world since 1830: background evidence and hypothesis." NBER, Historical Working Paper Number 36.

Williamson, G. Jeffrey. (1995). "Globalization, convergence and history." NBER, Working Paper Number 5259.

Williamson, G. Jeffrey, O’Rourke, Kevin and J. Timothy Hatton. (1993). "Mass migration, commodity market integration and real wage convergence: The late nineteenth century Atlantic economy." NBER, Historical Working Paper Number 48.

Williamson, G. Jeffrey. (1965). "Regional inequality and the process of national development: A description of patterns." Economic Development and Cultural Change, 13: 3-45.

WVBEP. (1992). "Employment and earning trends-annual summary 1991." West Virginia Bureau of Employment Programs. Charleston: Bureau of Employment Programs. 
Notes 

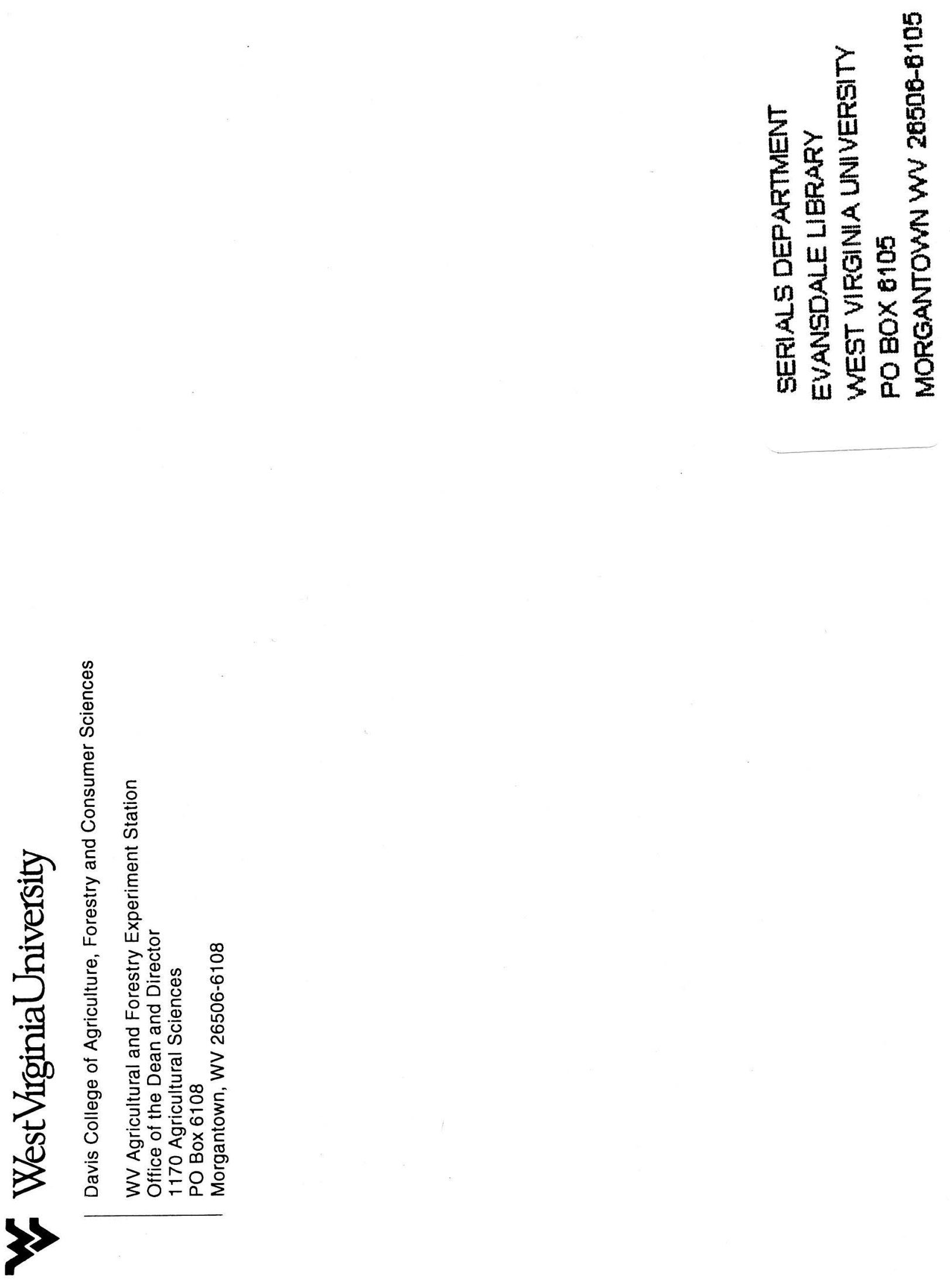